\title{
Hand hygiene knowledge, attitudes and practices among food handlers at primary schools in Hulu Langat district, Selangor (Malaysia)
}

\begin{abstract}
The purpose of this study was to investigate the hand hygiene knowledge, attitudes and practices of food handlers from 38 primary schools in Hulu Langat district, Selangor State in Malaysia. Hand hygiene knowledge, principally regarding ready-to-eat foods, the existence of bacteria and correct hand-washing methods were lacking among the food handlers. From the observations reported herein, the use of masks and hand-washing with proper technique were neglected by most food handlers. In the demographic profile analysed, there were significant differences $(\mathrm{p} \leq 0.05)$ in the following areas: hand-washing practices between genders $(\mathrm{p}=0.039)$, hand hygiene attitudes and glove use between nationalities $(\mathrm{p}=0.002$ and $\mathrm{p}=0.029$, respectively); and personal hygiene knowledge between groups with different levels of education $(\mathrm{p}=0.048)$. This study revealed a slightly positive relationship between hand hygiene knowledge and self-reported practices of food handlers $(r=0.249, p=0.022)$. The results showed that further continuous effort should be invested in hand hygiene education and enforcement for food handlers from primary schools in the Hulu Langat district. This study provided data about the current knowledge, attitudes and practices of food handlers from institutional foodservice operations in Malaysia regarding hand hygiene.
\end{abstract}

Keyword: Personal hygiene; Knowledge; Attitude; Practice; School foodservice operation 